\title{
DOMESTICATING REWILDING: INTERPRETING REWILDING IN ENGLAND'S GREEN AND PLEASANT LAND
}

Virginia Thomas

University of Exeter

Lazenby House

Prince of Wales Road

Exeter

England

Email:v.thomas4@exeter.ac.uk

\section{ABSTRACT}

There are many different forms and interpretations of rewilding: the concept and its practice vary from country to country, with distinct interpretations according to its geographical location. Despite the term rewilding having been present in the lexicon for three decades, the concept of rewilding in England has experienced a prolonged developmental stage. This paper argues that a unique form of English rewilding is now emerging, which is distinct from rewilding in other parts of the world. Compared to other locations rewilding in England operates at smaller spatial scales; its ambitions to increase biodiversity, restore ecosystem functioning and increase natural autonomy are somewhat curtailed; it involves higher levels of human intervention; and, perhaps most tellingly of all, it goes by another name - 'wilding', 'wild' or 'wilder' with little mention of the much-maligned prefix 're'. This conclusion has been developed following a comparative case study of two English 'rewilding' sites (the Avalon Marshes and Wild Ennerdale) involving 49 semi-structured interviews: twelve expert interviews and nineteen and eighteen stakeholder/practitioner interviews at the Avalon Mashes and Wild Ennerdale respectively.

\section{KEYWORDS}

Rewilding/wilding, wild/wilder, Avalon Marshes, Wild Ennerdale, England 


\section{INTRODUCTION}

Rewilding emerged as a conservation approach in the USA in the 1990s and was linked to the wilderness movement and the Wildlands Project (Jørgensen 2014; Lorimer et al. 2015). The concept focused on the idea of conserving nature by allowing apex predators (carnivores) sufficient space to insulate them from risk of extinction by linking up (corridors) protected areas (cores) and was therefore known as the 'three Cs' approach (Soule and Noss 1998). The concept expanded as it was adopted in other areas to focus on keystone species (those which 'in proportion to their biomass have a disproportionately large impact in an ecosystem' (Sandom et al. 2013: 431)) rather than apex predators, with an emphasis on their role in ecological restoration (Brown, McMorran and Price 2011; Stanley Price 2011). With this reliance on natural autonomy came arguments to reduce human intervention in conservation projects, leading some forms of rewilding to take a 'passive' approach and allow ecosystems to evolve without human management, something which can include 'land abandonment' i.e. leaving previously cultivated land to revert to an uncultivated state (Navarro and Pereira 2012).

While, at thirty years old, rewilding is coming of age, continuing debate makes it difficult to say that it has actually done so: rewilding is a contentious topic with ongoing discussion regarding its definition, and stakeholders and practitioners are still negotiating what the term means, and can mean, in principle and in practice (Prior and Brady 2017). Such controversy is heightened when rewilding occurs in 'culturally "layered" landscapes', not least because it challenges the 'cultural identities' based on human landscapes (Drenthen 2018) and the 'social constructions of [those] landscape[s]' (Wynne-Jones, Strouts and Holmes 2018). This is particularly the case in England where landscapes are 'culturally saturated' and where conservation has traditionally maintained that 'cultural richness' as opposed to addressing what can be framed as its 'ecologically denuded' state (Brook 2018). Since rewilding shifts the focus from 'traditional nature and landscape conservation', which protected 'agrarian landscapes', to ecological restoration, this creates conflict between 'Arcadian and wilderness visions' (Renes 2018).

This tension is shaping rewilding in a way that is unique to the English context (and distinct from other European forms of rewilding), which this paper identifies and describes as the 'domestication' of rewilding i.e. rewilding is being adapted to exist alongside people in England as compared to other countries where it has lower tolerance for human intervention and a tendency to exclude humans (Hintz 2007; Lorimer et al. 2015; Pettorelli et al. 2018). 
This view is compatible with that of other scholars who have shown that rewilding has different connotations depending on its geographical context (Jørgensen 2014); for example, as described above, rewilding in the USA focuses on the 'cores, corridors, and carnivores' approach (Soule and Noss 1998), whereas in Europe it is often more associated with the abandonment of farmland as a result of younger generations rejecting the low financial returns and hard manual work of farming and moving to cities (Navarro and Pereira 2012; Merckx and Pereira 2015; van der Zanden et al. 2017). This trend is related to global capitalism, with increasing urbanisation seeing a rise in demand for cheap, plentiful food in cities, driving agricultural incomes down and often leading to unsustainable farming practices that result in environmental degradation as agricultural production struggles to meet demand, further threatening financial stability (Killick 2001). This financial instability, coupled with the higher pay offered by jobs in urban areas, sees young people moving to the cities to take up new opportunities, which yet further destabilises the rural communities they leave behind (Killick 2001). Because the land left is marginal in terms of its productivity and is further marginalised by a lack of infrastructure, its low economic value means that it is simply deserted rather than sold (Navarro and Pereira 2012; Krauß and Olwig 2018).

In stark contrast to Europe, land 'abandonment' in the UK is rarely unintentional, usually occurring as a result of wealthy landowners dedicating land to low or no management strategies rather than because people simply walk away from land. In such scenarios, which have been called 'wildlands philanthropy' (Butler 2008), landowners transition often quite considerable areas of land from consumptive to non-consumptive use. As part of this deliberate abandonment strategy, Scotland demonstrates a rewilding model somewhat similar to the concept in the USA, albeit on a smaller scale, with possibilities for rewilding to occur at 'landscape scale' (Sandom et al. 2018) and with the prospect of large carnivore introductions forming a considerable part of the discourse (Hetherington 2005; Arts, Fischer and van der Wal 2012; Warren 2002). Wales and England, on the other hand, offer much more limited scope for rewilding in terms of spatial scale and are quite distinct, from Scotland and from each other, due to the historical and contemporary politics of the different nations. In Scotland rewilding can have connotations of the Highland Clearances (which saw mass rural depopulation in the Highlands and Islands in the 1700 and 1800s and thus produced a landscape denuded of people) (Brown, McMorran and Price 2011; Lorimer et al. 2015; Deary and Warren 2019; Shucksmith 2018; Wynne-Jones, Strouts and Holmes 2018). In Wales, there is tendency to view rewilding as a something of a neo-imperialist imposition wherein charities or non-governmental 
organisations based in England impose their rewilding agenda on Wales (Wynne-Jones, Strouts and Holmes 2018). In England meanwhile, the long history of human habitation, densely populated (and intensely cultural) landscape, and strong association with traditional nature and landscape conservation (e.g. via the National Trust), as discussed above, mean that changes in approach to land management, and to the relationship between humans and their environment, can conflict with deeply rooted and strongly held values. This resultant, distinctive shaping of rewilding in England produces a unique form of rewilding which is the focus of this paper. Rewilding in England happens on a smaller scale than in other places, does not necessarily self-identify as rewilding, has lower ambitions in terms of increasing biodiversity and restoring ecological function and has higher levels of human intervention and therefore lower levels of natural autonomy. This paper interprets this as rewilding in England being 'domesticated' (i.e. more amenable to humans, and accommodating of human presence and human intervention), in order to make it less culturally challenging and more palatable to English stakeholders.

\section{CLASSIFING REWILDING IN DIFFERENT LANDSCAPES}

The concept of rewilding was subject to considerable 'stretching' when it 'travelled' from the USA to other parts of the world (Collier and Mahon 1993) and, having initially possessed a clear definition, it became the centre of much debate as it was adopted, and adapted, in different locations and for different applications (Jørgensen 2014). Evident in this debate is 'boundary work' (Gieryn 1983), as practitioners and stakeholders attempt to dictate what rewilding does and can mean in the context of their local landscapes. Boundary work is used to analyse the way concepts are demarcated from one another and has previously been applied to ecological restoration (Keulartz 2009). It is particularly useful in examining rewilding since rewilding is a rapidly evolving, hotly contested and considerably confused concept in terms of definition and practice - its boundaries are therefore under constant negotiation and are being repeatedly redrawn.

The confusion and lack of consensus over a single definition is seen as problematic (NoguésBravo et al. 2016; Sandom et al. 2018), with calls for rewilding to be united under a common definition (Pettorelli et al. 2018). This paper does not therefore proffer another definition of rewilding, instead proposing a list of factors which could be said to constitute 'family resemblance' to rewilding (Wittgenstein 1968). This is helpful for two reasons: first, it recognises the 'cluster' of concepts that can be taken to constitute rewilding (Gammon 2018); and second, it offers a way of assessing rewilding sites and delineating rewilding from other 
conservation approaches (thereby contributing to the boundary work surrounding rewilding). This becomes useful when exploring rewilding in England as compared to other countries and where, as will be discussed in the results section of this paper, the boundaries between rewilding and 'conventional' conservation are somewhat blurred. The list of factors was drawn up from a review of the literature which examined, inter alia, the various definitions of rewilding that are proposed ${ }^{1}$ and from data gathered during the twelve expert interviews conducted as part of this research. It is extremely important to note that a conservation project need not display all the proposed factors in order to possess family resemblance to rewilding it must possess at least two, although of course may demonstrate more. The factors proposed as capable of conferring family resemblance to rewilding are: self-identification as rewilding, increase in biodiversity, restoration of ecological functioning, reduction of human intervention, increase in natural autonomy, large scale.

The utility of family resemblance as a way of approaching the identification or description of rewilding is that it accounts and allows for different views as to what is or is not required for rewilding. Spatial scale provides a good example of this: project size is rarely explicitly mentioned in formal definitions of rewilding, yet scale created considerable discussion during expert interviews conducted as part of this research; some experts emphasised the importance of rewilding projects being large, while others insisted that rewilding can occur at any scale (cf Prior and Brady 2017; Sandom et al. 2018). Further to this, it is even more difficult to identify exactly what is meant by 'large scale', with a paucity of literature quantifying what constitutes large scale (this becomes particularly relevant with regard to England, as will be discussed).

The linked aims of increasing other-than-human autonomy and decreasing human intervention are more commonly agreed goals (Navarro and Pereira 2012; Prior and Ward 2016; Tanasescu 2017; Deary and Warren 2019; Gammon 2018; Pettorelli et al. 2018; Sandom et al. 2018) but there can still be disagreement, for example over the extent to which human intervention can be used as a catalyst at the start of a rewilding project, if at all (Carver 2016; DeSilvey and Bartolini 2018). Increase in biodiversity, meanwhile, is a more commonly recognised goal of

\footnotetext{
${ }^{1}$ Definitions were drawn from Soule and Noss 1998; Höchtl, Lehringer, and Konold 2005; Navarro and Pereira 2012; Sandom et al. 2013; Jørgensen 2014; Sandom and Macdonald 2015; Arts, Fischer and van der Wal 2016; Corlett 2016; Nogués-Bravo et al. 2016; Carver 2016; Jepson 2016; Prior and Brady 2017; Tanasescu 2017; Crowley, Hinchliffe and McDonald 2017; Fernández, Navarro and Pereira 2017; Pettorelli et al. 2018; DeSilvey and Bartolini 2018; Gammon 2018.
} 
rewilding (Hintz 2007; Brown, McMorran and Price 2011; Navarro and Pereira 2012; Lorimer et al. 2015; Tsing 2017; Sandom et al. 2018) and is perhaps one of the main points of differentiation between rewilding and conventional conservation which, it could be argued, seeks only to maintain the status quo (Carver 2016). Increasing natural processes and ecological functioning was perhaps the least debated of goals, with broad consensus that this was, and should be, an aim of rewilding (Navarro and Pereira 2012; Lorimer et al. 2015; Sandom and Macdonald 2015; Arts, Fischer, and van der Wal 2016; Carver 2016; von Essen and Allen 2016; Jepson 2016; Nogués-Bravo et al. 2016; Prior and Ward 2016; Crowley, Hinchliffe and McDonald 2017; Prior and Brady 2017; Tanasescu 2017; Tsing 2017; Fernández, Navarro,and Pereira 2017; Sandom et al. 2018; Wynne-Jones, Strouts and Holmes 2018; DeSilvey and Bartolini 2018; Gammon 2018; Pettorelli et al. 2018; Ward and Prior 2020). This consensus regarding natural autonomy illustrates its centrality in rewilding, based on its relationship with wildness; increase in autonomy is linked to an increase in wildness, and is important for ecosystem flourishing independent of human control (Prior and Brady 2017). In particular, it is this increase in natural autonomy that, in addition to increase in biodiversity, distinguishes rewilding from other forms of ecological restoration (Ward and Prior 2020). Selfidentification as rewilding is another means of differentiating rewilding from other forms of conservation but can be unreliable since, as identified above, there is debate over when the term can, or should, be applied (Townsend 2016). Self-identifying as rewilding is therefore not independently sufficient to identify a case as rewilding and, inversely, not identifying as rewilding is not sufficient to preclude a project from being considered rewilding.

\section{METHODS}

The question this paper attempts to answer - i.e. 'how is rewilding interpreted and conducted in England' - arose from broader research investigating the boundaries human and physical landscapes present to rewilding and how these boundaries are negotiated. Two English 'rewilding' sites were used as case studies - the Avalon Marshes in Somerset in the southwest of England and Wild Ennerdale in Cumbria in England's northwest. Data collection was via semi-structured interviews, with fieldwork conducted from October 2018 to November 2019. A preliminary round of twelve expert interviews was performed, followed by nineteen and eighteen stakeholder and practitioner interviews at the Avalon Marshes and Wild Ennerdale respectively. Interviews were recorded, transcribed and then coded thematically using NVIVO12 software. 
The Avalon Marshes has restored land from its previous use for intensive agriculture and peat production to a mosaic of wildlife habitats and extensively farmed land. This involved an initial period of high intervention to create habitat, and restoration is ongoing - e.g. water management, tree planting and conservation grazing (although herbivores are excluded from certain areas of the site to control their impact, necessitating human management of vegetation in those areas). Similarly, Wild Ennerdale has restored a previously intensively farmed and forested valley to a more 'natural' state: intensive sheep faming has been largely replaced by naturalistic cattle grazing and commercial Sitka spruce plantation forestry is being replaced by the regeneration of native deciduous woodland. Some human intervention continues but, according to the Wild Ennerdale Partnership, interventions are strictly limited.

The case sites were selected to present contrasting contexts of rewilding in England. First, they are from either side of England's 'North-South divide', which has significant cultural as well as socioeconomic distinctions (Baker and Billinge 2004). Second, they are typographically very different: the Avalon Marshes are low-lying wetlands either at, or just above or below, sea level; Wild Ennerdale, by contrast, is an upland site, situated in England's Lake District, which contains many of England's highest peaks. Third, as has just been alluded to, water was a significant factor at the Avalon Marshes and also Wild Ennerdale, but interventions with regard to water were very different at each site. A highly interventionist approach is taken in, and around, the Avalon Marshes, with water levels controlled by mechanical pumping of water to control flooding. By contrast Wild Ennerdale has adopted a low to no intervention approach with regard to its water catchment and relies on natural processes as a flood response. Lastly, the two sites take different approaches to the term rewilding. The Avalon Marshes do not describe themselves as rewilding, framing themselves instead as having a more conventional, and interventionist, approach to conservation (Avalon Marshes 2020). Nonetheless external commentators $d o$ describe the Avalon Marshes as rewilding (e.g. Moss 2016; Taylor 2017; Macdonald 2019) and this can be justified, given the landscape scale ecological restoration occurring, the increase in biodiversity, the reduction (though not cessation) of human intervention and the other-than-human agency at play there. For example, certain species have effected 'auto-rewilding' (Tsing 2017; Ward and Prior 2020), reintroducing themselves to the area and recolonising the Marshes, illustrating an increase in natural autonomy (one of the tenets of rewilding). Wild Ennerdale is more associated with the term rewilding but still holds itself somewhat at arms-length from it. Wild Ennerdale does not for example title itself rewilding (preferring the epithet 'wild') or refer to rewilding on its website other than to declare 
that that it is 'excited to be a member of the European Rewilding Network' (Wild Ennerdale 2019). The avoidance versus (partial) use of the term rewilding allowed this research to explore stakeholder and practitioner relationships with the term, forming one of the major findings discussed in this paper.

\section{RESULTS AND DISCUSSION}

Despite the case sites being selected for their contrasting contexts, interview data from the Avalon Marshes and Wild Ennerdale revealed marked similarities in how rewilding was interpreted and conducted by practitioners, and perceived and received by stakeholders. At both case sites there was evidence that adaptations were being made to each of the factors proposed here as being capable of conferring family resemblance to rewilding. Each of these factors, and the adaptations to it, is addressed in turn in discussing the findings of this research. The adaptations show how some of rewilding's more radical potential is being moderated for the English context, making it easier for rewilding to operate with and alongside other land uses. The resulting, unique form of rewilding it is a 'domesticated' version of rewilding in other areas, scaled down terms of size, with limits on species (re)introductions, constraints on the autonomy of the other-than-human agents involved, requiring at least some level of human intervention, and even having limits on its scope for self-expression, inducing the epithet 'rewilding' to be replaced with the less provocative 'wilding'.

\section{Self-identification as rewilding}

Perhaps the most significant finding related to 'self-identification as rewilding'. Some participants were of the view that the term rewilding should be avoided either because it is inappropriate e.g. 'I don't think rewilding as a term, and as a methodology ... has any place at all' (Participant 11, expert), or because it is 'contentious' and 'controversial' (Participant 9, expert) and 'puts up a lot of backs' (Participant 2, expert). This finding is supported by the literature, which suggests rewilding has become 'toxic' (Sandom et al. 2018) and causes people (particularly farmers) to disengage with debate if it is used (Barkham 2017). Meanwhile, other participants were in favour of rehabilitating the term: for example, Participant 8 (expert) recognised that the media debate surrounding rewilding has resulted in some 'bad press' and talked of 'get[ting] rid' of the negative associations this had generated. This participant went on to discuss how, as a result of bad press, 'wilding' is now being used in preference to 'rewilding' in some instances ('wilding' is also the term favoured by Carver (2016) and Tree 
(2018)). She also suggested that if "rewilding is used the "re" should be interpreted as "restoring" rather than turning the clocks back'. This sentiment reiterates discussion in the literature around the use of 're' as being problematic, and similar attempts to emphasise that it should not be interpreted as regressive (Carver 2016; Tanasescu 2017; Deary and Warren 2019; Jepson 2018). The standpoint of this participant provides evidence of boundary work being performed in relation to rewilding, with stakeholders attempting to dictate how the prefix 're' should be understood.

Further boundary work was evident in interviews with other participants as they attempted to dictate what rewilding meant, particularly in the English context. They emphasised that rewilding is England is 'not about wolves and bears' (Participant 6, expert) and how that needed to 'become clear' to people. Attempts to make such things clear emerged in comments from another participant who was determined to keep using the term rewilding and to perform 'local tailoring' (Star 2010) to make it clear what it means in the English context: 'we will stick with that word [rewilding] ... and we will bring people to understand ... what we mean by rewilding, not what the purists mean (wolves and bears) what we mean' (Participant 5, expert). These attempts to rehabilitate the term appear not to have been entirely successful. For instance, as discussed above, neither of the case sites examined as part of this research have completely embraced the term rewilding. Perhaps more telling still is the recent increase in conservation projects which despite, like Wild Ennerdale, associating with the European Rewilding Network, do not use rewilding in their titles. For example, at the end of 2018 (when case sites for this research were selected) only two sites in England were listed as members of the European Rewilding Network, namely Wild Ennerdale and Knepp Wildland. Since then, three more projects have joined the network: Wallasea Island Wild Coast Project, Wicken Fen Vision and Wild Ken Hill, all of which conspicuously avoid using the term rewilding in their titles. A conclusion could be drawn that, as suggested by Participant 8, 'wild', without the prefix 're', is perhaps becoming the preferred term in England. This is reinforced by the title of the book about Knepp Wildland, called simply 'Wilding' (Tree 2018), despite charting the journey of what Tree herself describes as a 'rewilding project'.

Using 'wilding' is a way of addressing the unpalatability of the term 'rewilding', which is reportedly 'alienating [to] landowners and can't be mentioned to farmers' (Barkham 2017). Wilding, by contrast, is potentially more palatable and less threatening to stakeholders since the modification from 'rewilding' to 'wilding' subtly alters its connotations - rather than 
implying a return to a previous wild state it suggests only that conditions are getting to some degree wilder, thus making the concept more acceptable in the English context where an (incremental) increase in wildness is potentially acceptable but a return to complete wilderness is unpalatable. The unpalatability of any such return to wilderness is due, as discussed above, to the long history of human habitation and extensive human modification of England's landscapes to the point that they are now almost entirely cultural (Smout 2000; Carver 2007; Linnell et al. 2015; Sandom and Macdonald 2015). These cultural landscapes are now embedded in England's national consciousness and are valued specifically for the human interactions with land that have created the 'rural idylls' and 'chocolate box' villages considered representative of beauty in the context of the English countryside (Short 2002; Wylie 2007). Rewilding or wildness is therefore contrary to English ideas, and ideals, of the landscape as a managed one, and is viewed negatively as a rejection of the interaction of people with the land and as aesthetically and culturally conflicting with the profoundly cultural landscape (Prior and Brady 2017).

\section{Increase in biodiversity and restoration of ecological functioning}

Rewilding's major tenet of increasing biodiversity is somewhat qualified in the English context. England's, or rather Britain's, island status contributes to this considerably, since it means that extirpated species face a significant natural barrier to autonomous reintroduction. This presents rewilding practitioners with a dilemma - intervene to reintroduce absent species, thus contravening rewilding's non-intervention approach, or operate without these species, some of which may be 'keystone species'. The act of intervention raises considerable debate, with species reintroductions via human intervention being even more contentious than those that occur 'naturally', which provoke considerable controversy in themselves (Arts, Fischer and van der Wal 2012).

This dilemma, and the attendant controversy, is most noticeable in, though not exclusive to, the case of large carnivores. Large predators have been absent from England, and indeed Britain, for centuries and the debate concerning their reintroduction is often a heated one. The local tailoring of rewilding in England described above to disassociate it from large carnivore reintroductions has not been entirely successful, despite the fact that proposals to reintroduce such species (typically the Eurasian lynx (Lynx lynx) and the Eurasian wolf (Canis lupus)) are relatively limited with respect to England, especially as compared with Scotland. Indeed, as seen above, participants in this research were at pains to stress that large carnivores were not 
part of a rewilding agenda in England and yet rewilding remains 'almost synonymous in people's mind with large carnivore reintroduction' (Participant 2, expert) and inextricably associated with the 'debate about predators' (Participant 22, practitioner). Stakeholders at both case sites spoke of their fears regarding the reintroduction of wolves and/or lynx associated with rewilding and the impact that this would have on rural, particularly farming, livelihoods saying:

going back to the rewilding subject, I certainly don't agree with this about lynx and wolves ... you've got someone living next-door, farming that land, trying to make a living, and when he's lambing or calving in the spring, to that wild animal that's just like us going to a McDonald's ... they just go behind a sheep and pick a lamb up, but that's that man's living, and that's why I don't think it can work and I don't think it should even be entertained ... how can you have an impact on a man's living because of a whim of someone wanting to rewild (Participant 30, stakeholder).

It should be noted that the Avalon Marshes, which this participant was discussing, has no plans to reintroduce the large carnivores he fears could have an impact on 'a man's living'; nevertheless, for him, rewilding and large carnivore reintroductions appear to be inextricably linked. Proposals to reintroduce large carnivores are largely absent from the rewilding discourse in England and this absence, or rather deliberate removal of these predators from the rewilding agenda, provides further evidence of the boundary work being conducted in relation to rewilding and of the way English rewilding is being 'domesticated', with attempts to make it (appear) safer and less threatening to those who will be most affected by it e.g. farmers/land owners. A result of this domestication of rewilding in England, via the exclusion of certain companion species of rewilding, is that the intended increase in biodiversity is, at least to some extent, curtailed. This is particularly true since controversy over reintroductions is not limited to large carnivores, with even reintroductions of herbivores (e.g. beaver, Castor fiber), omnivores (e.g. boar, Sus scrofa) and small carnivores (e.g. wildcats, Felis silvestris) arousing significant debate, highlighting the highly anthropogenic environment that has become normalised and the associated loss of tolerance for living alongside other species (Murray 2017).

The absence of these species from England, and the lowering of ambition to increase biodiversity that is related to reluctance to reintroduce them, means that some ecological niches 
are empty. This has significant impacts on ecological functioning, as trophic cascades, food webs and even habitats are disrupted. This impact becomes still more significant if the missing species are ecosystem engineers and/or keystone species. This is illustrated in a quote from a participant who said that, rewilding projects in England, 'won't get the carnivores, so you'll have to act as the carnivore to sort of keep that in balance' (Participant 5, expert). This comment highlights the effect that species being missing has on ecosystem function and the resultant 'requirement' for human intervention to 'balance' an ecosystem which has not had full function restored. Once again this illustrates that rewilding in England is somewhat abridged - its aim of restoring ecological function can be fulfilled to some extent but it is limited by the availability of species; and it will not be able to fully restore ecological functioning unless and until all ecological niches are filled. This curtailment is another aspect of rewilding's domestication in England as compared to other countries (potentially even as compared to Scotland which is proposed as a much more feasible site for the reintroduction of lynx and/or wolves than England), which often have a fuller suite of native species.

\section{Reduction of human intervention and increase in natural autonomy}

As discussed above, some level of human intervention continues at both the Avalon Marshes and Wild Ennerdale, despite reduction of human intervention being a key aim of rewilding. This continued human intervention may assist in making rewilding more palatable to those whom it affects most directly, particularly farmers and other land managers, with its domestication making it more compatible with and able to exist alongside current land use. Indeed, farmers and land managers interviewed as part of this research argued strongly for continued management of England's countryside for many reasons: to conserve heritage and cultural landscape, to protect biodiversity, to maintain rural livelihoods and communities and to assist in providing national food security. They argued that extensive farming, involving some human intervention in the landscape, could achieve these ends: 'you can increase biodiversity with human processes, you can increase it through agriculture, you can increase levels of species richness by introducing grazing regimes that still are part of a productive system' (Participant 11, stakeholder). Extensive farming is potentially compatible with rewilding - indeed it is part of both the Avalon Marshes and Wild Ennerdale - but again signifies a compromise to rewilding's principles since it involves human processes and a consumptive use of land. One participant saw this as 'tak[ing] you closer to the wood pasture type model' and, as a result, making rewilding 'more acceptable to mainstream rural dwellers' 
(Participant 10, expert). Such an approach may assuage the concerns of another participant who suggested that 'what you'd end up with is really a lot of rubbish if you didn't manage it [land]' (Participant 41, stakeholder). This perspective is the culmination of millennia of management of the English landscape which has resulted in the idea of 'man as manager', a notion antithetical to rewilding and, conversely, what makes rewilding an anathema to so many landowners, as reflected by Participant 41's comment. In addition to this, both the Avalon Marshes and Wild Ennerdale contain important archaeological sites which, if rewilding were allowed to progress without human intervention, could potentially be lost. Given the importance of conserving England's heritage, interventions occur at both sites to maintain the integrity of their archaeology: 'the volunteer group actually stay on top of the grass growth and the regrowth because they come up here every now and again and strim all the vegetation and remove any new tree growth and that keeps it [the archaeology] all available' (Participant 16, practitioner).

While maintaining cultural landscapes, such ongoing human intervention has impacts on nonhuman autonomy; however, since natural autonomy can be viewed as a continuum rather than in a binary fashion, rewilding at both the Avalon Marshes and Wild Ennerdale can be said to have increased natural autonomy, though not to the extent that might occur in other countries, e.g. parts of Europe. For example, with respect to the companion species of rewilding, the cattle involved in the rewilding projects at the Avalon Marshes and Wild Ennerdale could be seen as having far greater autonomy than their more intensively farmed counterparts (e.g. 'the Galloways ... their options are massively different to the farmed cows at home' (Participant 34, stakeholder)). Their level of autonomy is, however, still far lower than that of wild bovines, bovines involved in other rewilding projects (e.g. the Heck cattle of the Oostvaardersplassen) or even the roe deer which inhabit both sites. Natural autonomy has both risks and benefits for the species involved. High degrees of autonomy mean that the species possess 'sovereignty' (von Essen and Allen 2016) and are at liberty with respect to their breeding, feeding and roaming. Lower degrees of autonomy often mean that these liberties are restricted, but there are usually associated compensations e.g. provision of food, shelter and care in case of illness and injury. So, while highly autonomous companion species of rewilding may be granted sovereignty, they may be excluded from the regimes of care that humans extend to captive or domestic species - what von Essen and Allen (2016) refer to as 'negative rights of noninterference'. DeSilvey and Bartolini (2018) and Ward and Prior (2020) describe these differences in autonomy ascribed to species in different circumstances as 'situated', in that they 
are 'uneven' and 'variable across locations'. Situated autonomy is clearly visible in the context of English rewilding, with the limited degrees of natural autonomy afforded in English rewilding sites being another factor that domesticates rewilding in England (and, potentially, reduces the controversy associated with it). For example, 'allowing' animals to starve to death, as happened in the Oostvaardersplassen in the winter of 2004/2005, may not impinge upon their sovereignty but can be highly contentious in terms of public opinion, as was indeed the case at the Oostvaardersplassen (Lorimer and Driessen 2014; Lorimer and Driessen 2013; Keulartz 2009). In the case sites studied for this research, by contrast, care is commonly extended to the companion species involved, reducing their autonomy but also avoiding potential suffering and death, and related public outrage. This concern for the wellbeing of companion species of rewilding is exemplified in a quote from a participant who described the extensive farming element of the Wild Ennerdale project as

geared around the welfare, the animal health side of things. Because we couldn't do it and have poor cows ... we've got to consider that as our main priority and our environmental scheme really comes on the back of that. We've got to make sure we have a healthy cow (Participant 34, stakeholder).

This comment illustrates a marked difference in approach between Wild Ennerdale and the Oostvaardersplassen. Natural autonomy is privileged over animal welfare at the Oostvaardersplassen with cattle being 'allowed' to die in accordance with their individual sovereignty. At Wild Ennerdale, by contrast, animal health is prioritised over natural autonomy and cattle are not allowed to die, curtailing their autonomy but protecting their wellbeing. By moderating natural autonomy and permitting it to increase to only a limited extent, practitioners are further domesticating rewilding in England, making it more acceptable in the English context.

\section{Large scale}

One of the arguments to emerge in the literature on rewilding and, more especially, in the interview data for this research, was that, as a rule, rewilding should operate at 'large' or 'landscape' scale; otherwise you're 'just doing it really at a nature reserve scale' (Participant 5, expert). This was not a hard and fast rule however, with concessions being made regarding the scale at which rewilding could, or should, occur, especially in relation to England. This was evident in the interview data, with one participant suggesting that rewilding should not be 
restricted 'to just being large-scale', acknowledging that there is not the scope for extensive projects in England and that therefore we should not 'start setting a size' on rewilding (Participant 8, expert). Evidence of this can also be seen in comments from Alastair Driver, the director of the charity Rewilding Britain. In a media interview, Driver defined large scale as '10,000 ha plus in England, Wales and Northern Ireland and 100,000 ha plus in Scotland' (Catchments 2018). What is notable is that, like the concept of rewilding itself, its practicalities can be seen as being geographically specific. While he does 'set a size for rewilding', Driver moderates this scale for Northern Ireland, Wales and England. What is even more notable, however, is not only that case sites for this research are less than half that size in the case of Wild Ennerdale (4,300 hectares) and less than a quarter in the case of the Avalon Marshes (1,500 hectares), but that none of the English sites that are part of the European Rewilding Network are close to 10,000 hectares. $^{2}$ Thus, not only is rewilding in England operating at a much smaller scale than in Scotland (where 'Rewilding the Scottish Highlands' is 12,000 hectares and Coigach and Assynt Living Landscape is 60,000 hectares) and other parts of Europe (for example Swedish Lapland is 3,550, 154 hectares (Rewilding Europe 2020b)) but it is operating at a much smaller scale than its proponents would advocate.

This 'scaling down' is another aspect of the domestication of rewilding in England, with one participant describing the size of Wild Ennerdale as being a 'reasonable scale in this part of the world' (Participant 35, practitioner), while another would like to see it scaled down further: 'scale it down a bit, certain areas within an area rather than a ... full valley of the Lake District' (Participant 41, stakeholder). In reducing the spatial scale at which rewilding operates, practitioners are taming rewilding, making it less threatening to an English audience and more compatible with the English context where available land is limited, has a high economic value, is subject to competing demands and often abuts with conflicting land use, and excluding humans, and their interventions, would be controversial. This was clear in the interview data, with one participant contrasting the scope for rewilding in the Lake District with that of Canada saying of Wild Ennerdale 'you could never make this a truly wild landscape because it's not got the scale. I think you'd need to be somewhere like Canada ... And on this scale, even though it's nice to see and large, it's never going to be self-regulating, it's always going to need management' (Participant 17, stakeholder). This participant's comments again point to the way in which the restrictions on one aspect of rewilding (spatial scale) have implications for other

\footnotetext{
${ }^{2}$ Wild Ken Hill stands at 425 hectares, Wallasea Island Wild Coast Project at 850 hectares, Knepp Wildland at 1,400 hectares, and Wicken Fen Vision at 5,300 hectares (Rewilding Europe 2020a).
} 
aspects (reduction of human intervention), with management of land being perceived as necessary in smaller areas which cannot be 'self-regulating'.

\section{CONCLUSION}

As is demonstrated in the foregoing discussion, each of the factors identified as capable of conferring family resemblance to rewilding is significantly modified in the context of the Avalon Marshes and Wild Ennerdale. It is possible to extrapolate from these cases to draw conclusions regarding rewilding in England more generally and how the factors capable of conferring family resemblance to rewilding are modified for the English context. This extrapolation is made possible by the similarities in approaches and attitudes to rewilding evident between the Avalon Marshes and Wild Ennerdale, despite their different contexts. Commonalities between the local tailoring of rewilding evident at the Avalon Marshes and Wild Ennerdale, and in attitudes from rewilding experts with respect to rewilding in England, suggest that local tailoring of rewilding is happening at an England-wide level from which a uniquely English form of rewilding is emerging. This paper does not, however, propose a normative approach to what can or cannot be considered rewilding and does not suggest that this precludes English rewilding sites such as the Avalon Marshes and Wild Ennerdale from being considered as falling somewhere on the rewilding spectrum. Rather it suggests that English rewilding is a unique, domesticated form of rewilding distinct from rewilding in other parts of the world, Europe and even the UK: i.e. it self-identifies as 'wilding' rather than 'rewilding', it occurs on a smaller scale, its aspirations to increase biodiversity are somewhat restricted, thereby partially limiting its ability to restore ecological functioning and thus requiring ongoing levels of human intervention (which may not occur in rewilding in other locations), which therefore impedes natural autonomy.

The adaptations to the concept of rewilding mean that rewilding in England is closer to, and harder to distinguish from, what might be called conventional conservation. That is not to say that it is totally indistinguishable, although the distinction may be conceptual rather than physical. According to its proponents, rewilding offers what might be called a "new narrative of hope' (Lawton 2020) as opposed to conventional conservation, which is sometimes portrayed as fighting a 'rear-guard action' in the face of declining biodiversity and habitat loss. There is also an argument that rewilding and conventional conservation can, or rather should, be complementary conservation techniques, rather than rewilding being seen as new mode of conservation which seeks to replace other methods (Meech 2016). The modification of 
rewilding in the English context may make it easier to achieve this successfully, not least by making rewilding acceptable in a way that its previous, unmodified form is not. In order for rewilding to make any meaningful contribution to conservation in England, it is necessary for it to be accepted by publics, particularly the publics whom it will most affect. Rewilding may be (working towards) achieving that acceptability through the modification of some of its more radical, and contentious, proposals and, as a result, it may find that it can make a greater contribution to conservation than it could by attempting to adhere more rigidly to those goals.

\section{REFERENCES}

Arts, K., A. Fischer and R. van der Wal. 2012. 'Common stories of reintroduction: a discourse analysis of documents supporting animal reintroductions to Scotland'. Land Use Policy 29 (4): 911-20.

\section{https://doi.org/10.1016/j.landusepol.2012.01.009}

Arts, K., A. Fischer and R. van der Wal. 2016. 'Boundaries of the wolf and the wild: a conceptual examination of the relationship between rewilding and animal reintroduction'. Restoration Ecology 24 (1): 27-34.

\section{https://doi.org/10.1111/rec.12309}

Avalon Marshes. 2020. 'The Avalon Marshes'. http://avalonmarshes.org/.

Baker, A. and M. Billinge (eds). 2004. Geographies of England: The North-South Divide, Material and Imagined. Cambridge: Cambridge University Press.

\section{https://doi.org/10.1017/CBO9780511550775}

Barkham, P. 2017. "“It is strange to see the British struggling with the beaver": why is rewilding so controversial?' The Observer, July 2017.

Brook, I. 2018. 'Restoring or re-storying the Lake District: applying responsive cohesion to a current problem situation'. Environmental Values 27 (4): 427-445.

\section{https://doi.org/10.3197/096327118X15251686827750}

Brown, C., R. McMorran and M. Price. 2011. 'Rewilding - a new paradigm for nature conservation in Scotland?' Scottish Geographical Journal 127 (4): 288-314. 
https://doi.org/10.1080/14702541.2012.666261

Butler, T. 2008. Wildlands Philanthropy. Riverside: Earth Aware Editions.

Carver, S. 2007. 'Rewilding in England and Wales: a review of recent developments, issues, and concerns', in A. Watson, J. Sproull and L. Dean (eds), Science and Stewardship to Protect and Sustain Wilderness Values, pp. 267-272. Anchorage: US Department of Agriculture, Forest Service.

Carver, S. 2016. 'Rewilding... conservation and conflict'. Ecos 37 (2): 2-10.

Catchments. 2018. 'Time to rewild?' https://www.catchments.ie/time-to-rewild-a-view-fromacross-the-irish-sea/.

Collier, D. and J. Mahon. 1993. 'Conceptual "stretching" revisited: adapting categories in comparative analysis'. The American Political Science Review 87 (4): 845-55.

\section{https://doi.org/10.2307/2938818}

Corlett, R. 2016. 'Restoration, reintroduction, and rewilding in a changing world'. Trends in Ecology and Evolution 31 (6): 453-62.

\section{https://doi.org/10.1016/j.tree.2016.02.017}

Crowley, S., S. Hinchliffe and R. McDonald. 2017. 'Nonhuman citizens on trial: the ecological politics of a beaver reintroduction'. Environment and Planning A 49 (8): 1846-66.

\section{https://doi.org/10.1177/0308518X17705133}

Deary, H. and C.R. Warren. 2019. 'Trajectories of rewilding: a taxonomy of wildland management'. Journal of Environmental Planning and Management 62 (3): 466-91.

https://doi.org/10.1080/09640568.2018.1425134

DeSilvey, C. and N. Bartolini. 2018. 'Where horses run free? Autonomy, temporality and rewilding in the Côa Valley, Portugal'. Transactions of the Institute of British Geographers 44 (1): 1-16.

https://doi.org/10.1111/tran.12251 
Drenthen, M. 2018. 'Rewilding in layered landscapes as a challenge to place identity'. Environmental Values 27 (4): 405-425.

\section{https://doi.org/10.3197/096327118X15251686827732}

Essen, E. von and M. Allen. 2016. 'Wild, but not too-wild animals: challenging Goldilocks standards in rewilding'. Between the Species 19 (1): 80-108.

Fernández, N., L. Navarro and H. Pereira. 2017. 'Rewilding: a call for boosting ecological complexity in conservation'. Conservation Letters 10 (3): 276-78.

https://doi.org/10.1111/conl.12374

Gammon, A. 2018. 'The many meanings of rewilding: an introduction and the case for a broad conceptualisation'. Environmental Values 27: 331-50.

\section{https://doi.org/10.3197/096327118X15251686827705}

Gieryn, T. 1983. 'Boundary-work and the demarcation of science from non-science : strains and interests in professional ideologies of scientists'. American Sociological Review 48 (6): 781-95.

\section{https://doi.org/10.2307/2095325}

Hetherington, D. 2005. 'The feasibility of reintroducing the Eurasian lynx (Lynx lynx) to Scotland'. University of Aberdeen.

Hintz, J. 2007. 'Some political problems for rewilding nature'. Ethics, Place and Environment 10 (2): 177-216.

\section{https://doi.org/10.1080/13668790701344774}

Höchtl, F., S. Lehringer and W. Konold. 2005. “Wilderness”: what it means when it becomes a reality - a case study from the southwestern Alps'. Landscape and Urban Planning 70 (1-2): 85-95.

\section{https://doi.org/10.1016/j.landurbplan.2003.10.006}

Jepson, P. 2016. 'A rewilding agenda for Europe: creating a network of experimental reserves'. Ecography 39: 117-24. 
Jepson, P. 2018. 'Recoverable Earth: A twenty-first century environmental narrative'. Ambio, 2018.

https://doi.org/10.1007/s13280-018-1065-4

Jørgensen, D. 2014. 'Rethinking rewilding'. Geoforum 65: 482-88.

https://doi.org/10.1016/j.geoforum.2014.11.016

Keulartz, J. 2009. 'Boundary work in ecological restoration'. Environmental Philosophy 6 (1): $35-56$.

https://doi.org/10.5840/envirophil2009613

Killick, T. 2001. 'Globalisation and the rural poor'. Development Policy Review 19 (2): 155180.

https://doi.org/10.1111/1467-7679.00129

Krauß, W. and K. Olwig. 2018. 'Special issue on pastoral landscapes caught between abandonment, rewilding and agro-environmental management. Is there an alternative future?' Landscape Research 43 (8): 1015-20.

https://doi.org/10.1080/01426397.2018.1503844

Lawton, G. 2020. 'We should rewild the sky to restore the atmosphere to its former glory'. New Scientist, August 2020.

https://doi.org/10.1016/S0262-4079(20)31455-X

Linnell, J.D.C. et al. 2015. 'Framing the relationship between people and nature in the context of European conservation'. Conservation Biology 29 (4): 978-985.

https://doi.org/10.1111/cobi.12534

Lorimer, J. and C. Driessen. 2014. 'Wild experiments at the Oostvaardersplassen: rethinking environmentalism in the anthropocene'. Transactions of the Institute of British Geographers 39 (2): 169-81.

\section{https://doi.org/10.1111/tran.12030}

Lorimer, J. and C. Driessen. 2013. 'Bovine biopolitics and the promise of monsters in the rewilding of Heck cattle'. Geoforum 48: 249-59. 
https://doi.org/10.1016/j.geoforum.2011.09.002

Lorimer, J., C. Sandom, P. Jepson, C. Doughty, M. Barua and K.J. Kirby. 2015. 'Rewilding: science, practice, and politics'. Annual Review of Environment and Resources 40: 39-62.

https://doi.org/10.1146/annurev-environ-102014-021406

Macdonald, B. 2019. Rebirding: Rewilding Britain and its Birds. Exeter: Pelagic Publishing.

Meech, H. 2016. 'Wilder visions, wilder lives, wilder nature?' Ecos 37 (2): 19-23.

Merckx, T. and H. Pereira. 2015. 'Reshaping agri-environmental subsidies: from marginal farming to large-scale rewilding'. Basic and Applied Ecology.

https://doi.org/10.1016/j.baae.2014.12.003

Moss, S. 2016. Wild Kingdom: Bringing Back Britain's Wildlife. London: Square Peg.

Murray, M. 2017. 'Wild pathways of inclusive conservation'. Biological Conservation 214: 206-12.

https://doi.org/10.1016/j.biocon.2017.08.028

Navarro, L.M. and H.M. Pereira. 2012. 'Rewilding abandoned landscapes in Europe'.

Ecosystems 15 (6): 900-912.

https://doi.org/10.1007/s10021-012-9558-7

Nogués-Bravo, D., D. Simberloff, C. Rahbek and N. Sanders. 2016. 'Rewilding is the new Pandora's box in conservation'. Current Biology 26 (3).

https://doi.org/10.1016/j.cub.2015.12.044

Pettorelli, N., J. Barlow, P. Stephens, S. Durant, B. Connor, H. Schulte to Bühne, C. Sandom, J. Wentworth and J. du Toit. 2018. 'Making rewilding fit for policy'. Journal of Applied Ecology 55 (3): 1-12.

https://doi.org/10.1111/1365-2664.13082

Prior, J. and E. Brady. 2017. 'Environmental aesthetics and rewilding'. Environmental Values 26 (1): $31-51$.

https://doi.org/10.3197/096327117X14809634978519 
Prior, J. and K. Ward. 2016. 'Rethinking rewilding: a response to Jørgensen'. Geoforum 69: $132-35$.

\section{https://doi.org/10.1016/j.geoforum.2015.12.003}

Renes, H. 2018. 'New nature in old landscapes: some Dutch examples of the relation between history, heritage and ecological restoration'. Environmental Values 27 (4): 351-375.

\section{https://doi.org/10.3197/096327118X15251686827714}

Rewilding Europe. 2020a. 'European rewilding network'.

https://rewildingeurope.com/european-rewilding-network/.

Rewilding Europe. 2020b. 'Swedish Lapland'. https://rewildingeurope.com/rewproject/lapland-rewilding-area/.

Sandom, C. and D. W. Macdonald. 2015. 'What next? Rewilding as a radical future for the British countryside'. In D.W. MacDonald and R.E. Feber (eds), Wildlife Conservation on Farmland Volume 1: Managing for Nature in Lowland Farms, pp. 291-316. Oxford: Oxford University Press.

\section{https://doi.org/10.1093/acprof:oso/9780198745488.003.0016}

Sandom, C., B. Dempsey, D. Bullock, A. Ely, P. Jepson, S. Jimenez-Wisler, A. Newton, N. Pettorelli and R. Senior. 2018. 'Rewilding in the English uplands: policy and practice'. Journal of Applied Ecology 56 (2): 266-73.

\section{https://doi.org/10.1111/1365-2664.13276}

Sandom, C., J. Donlan, J.C. Svenning and D. Hansen. 2013. 'Rewilding'. In Key Topics in Conservation Biology 2, pp. 430-51. Chichester: John Wiley \& Sons.

\section{https://doi.org/10.1002/9781118520178.ch23}

Short, L. 2002. 'Wind power and English landscape identity'. In M.J. Pasqualetti, P. Gipe and R.W. Righter (eds), Wind power in view: energy landscapes in a crowded world pp. 43-58. London: Academic Press. Shucksmith, M. 2018. 'Re-imagining the rural: from rural idyll to good countryside'. Journal of Rural Studies 59: 163-72. 
Smout, T.C. 2000. Nature Contested: Environmental History in Scotland and Northern England Since 1600. Edinburgh: Edinburgh University Press.

Soule, M. and R. Noss. 1998. 'Rewilding and biodiversity: complementary goals for continental conservation'. Wild Earth 8 (3): 18-28.

Star, S.L. 2010. 'This is not a boundary object: reflections on the origin of a concept'. Science Technology and Human Values 35 (5): 601-17.

\section{https://doi.org/10.1177/0162243910377624}

Stanley Price, M.R. 201. 'Reintroductions in today's Arabian Peninsula: the first steps for a grander vision?' Zoology in the Middle East 54 Supplementum 3: 159-167.

\section{https://doi.org/10.1080/09397140.2011.10648907}

Tanasescu, M. 2017. 'Field notes on the meaning of rewilding'. Ethics, Policy and Environment 20 (3): 333-49.

\section{https://doi.org/10.1080/21550085.2017.1374053}

Taylor, P. 2017. 'Hard Brexit - soft rewilding?' Ecos 38(1).

Townsend, M. 2016. 'Rewilding - keeping the brand integrity'. Ecos 37 (2): 29-34.

Tree, I. 2018. Wilding. London: Picador.

Tsing, A. 2017. 'The buck, the bull, and the dream of the stag: some unexpected weeds of the anthropocene'. Suomen Antropologi 42 (1): 3-21.

Ward, K. and J. Prior. 2020. 'The reintroduction of beavers to Scotland: rewilding, biopolitics and the affordance of non-human autonomy', Conservation and Society 18 (2): 103-113.

\section{https://doi.org/10.4103/cs.cs_19_63}

Warren, C. 2002. Managing Scotland's Environment. Edinburgh: Edinburgh University Press.

Wild Ennerdale. 2019. 'Wild Ennerdale'. http://www.wildennerdale.co.uk/.

Wittgenstein, L. 1968. Philosophical Investigations. London: Blackwell. 
Wylie, J. 2007. Landscape. Oxon: Routledge.

Wynne-Jones, S., G. Strouts and G. Holmes. 2018. 'Abandoning or reimagining a cultural heartland? Understanding and responding to rewilding conflicts in Wales - the case of the Cambrian Wildwood'. Environmental Values 27 (4): 377-403.

Zanden, E. van der, P. Verburg, C. Schulp and P. Johannes Verkerk. 2017. 'Trade-offs of European agricultural abandonment'. Land Use Policy 62: 290-301. 